\title{
PENGARUH PENGETAHUAN KEAGAMAAN DAN KECERDASAN EMOSIONAL TERHADAP PRILAKU SOSIAL ANAK DI SDIT NUR EL QOLAM SERANG BANTEN
}

\section{Syamsul Bahri Tanrere ${ }^{1}$}

Institut PTIQ Jakarta

Email: s_tanrere@yahoo.com

\section{Otong Surasman ${ }^{2}$}

Institut PTIQ Jakarta

Email: otongmomonsurasman@gmail.com

\author{
Ahmad Mubarok ${ }^{3}$ \\ Institut PTIQ Jakarta \\ Email: ahmadmubarokb@gmail.com
}

\begin{abstract}
ABSTRAK
Penelitian ini bertujuan untuk mendapatkan pemahaman data-data empirik mengenai Pengaruh Pengetahuan Keagamaan dan Kecerdasan Emosional, baik secara sendiri-sendiri maupun secara bersama-sama dengan Perilaku Sosial Siswa SDIT Nur El Qolam Serang Banten. Hipotesis penelitian ialah (1) Terdapat pengaruh yang erat dan signifikan Pengetahuan Agama terhadap Perilaku Sosial Siswa SDIT Nur El Qolam Serang Banten (2) Terdapat pengaruh yang erat dan signifikan Kecerdasan Emosional terhadap Perilaku Sosial Siswa SDIT Nur El Qolam Serang Banten.

Dalam penelitian ini penulis menggunakan metode survei dengan pendekatan korelasional yang di laksanakan di SDIT Nur El Qolam Serang Banten dengan melibatkan Siswa Kelas, empat, lima dan enam. Pengumpulan data dilakukan dengan observasi, wawancara, angket, dan studi dokumenter. Analisis data menggunakan analisis korelasional dengan teknik korelasi rumus product moment. Hasil pengujian hipotesis sebagai berikut:

Pertama, terdapat pengaruh positif dan rendah antara Pengetahuan Agama dengan Perilaku Sosial Siswa SDIT Nur El Qolam Serang Banten. Selanjutnya karena koefisien korelasi $\mathrm{r}=0,230$ maka dapat diperoleh nilai koefisien determinasinya sebesar $R_{2}=0,053$ yang berarti bahwa $05,3 \%$ variansi Perilaku Sosial Siswa SD SDIT Nur El Qolam Serang Banten melalui persamaan regresi : $\hat{\mathrm{Y}}=72,209+0,115 \mathrm{X}_{1}$ yang signifikan pada taraf alpha 0,05 .

Kedua, terdapat pengaruh positif dan sedang antara Kecerdasan Emosional dengan Perilaku Sosial Siswa SDIT Nur El Qolam Serang Banten. Selanjutnya karena koefisien korelasi $\mathrm{r}=0,159$ maka dapat diperoleh nilai koefisien determinasinya sebesar $R_{2}=0,025$ yang berarti bahwa $02,5 \%$ variansi Perilaku Sosial Siswa SDIT Nur El Qolam Serang Banten dapat dipengaruhi oleh Kecerdasan Emosional melalui persamaan regresi : $\hat{\mathrm{Y}}=74,602+0,095 \mathrm{X}_{2}$ yang signifikan pada taraf alpha 0,05 .

Ketiga, terdapat pengaruh positif dan sedang antara Pengetahuan Agama dan Kecerdasan Emosional dengan Perilaku Sosial Siswa SDIT Nur El Qolam Serang Banten. Selanjutnya karena koefisien korelasi $r=0,232$ maka dapat diperoleh nilai koefisien determinasinya sebesar $\mathrm{R}_{2}=0,054$ yang berarti bahwa
\end{abstract}


05,4 \% variansi Perilaku Sosial Siswa SD SDIT Nur El Qolam Serang Banten dapat dipengaruhi oleh Pengetahuan Agama dan Kecerdasan Emosional melalui persamaan regresi : $\hat{\mathrm{Y}}=70,662+0,104 \mathrm{X}_{1}+0,024 \mathrm{X}_{2}$ yang signifikan pada taraf alpha 0,05 .

Temuan ini diharapkan mampu memberikan kontribusi yang positif bagi pembinaan Pengetahuan Agama dan Kecerdasan Emosional Terhadap Perilaku Sosial SDIT Nur El Qolam Serang Banten pada generasi yang ada dan generasi selanjutnya.

Kata Kunci : Pengetahuan Agama Islam, Kecerdasan Emosional dan Prilaku Sosial 


\section{ABSTRACT}

This study aims to gain an understanding of empirical data regarding the Effects of Religious Knowledge and Emotional Intelligence, both individually and jointly with the Social Behavior of SDIT Nur El Qolam Serang Students Banten. Research hypotheses are (1) There is a close and significant influence of Religious Knowledge on Social Behavior of SDIT Nur El Qolam Serang Banten Students (2) There is a close and significant influence on Emotional Intelligence on Social Behavior of SDIT Nur El Qolam Serang Banten SDIT Students.

In this study the authors used a survey method with a correlational approach that was carried out at SDIT Nur El Qolam Serang Banten by involving Class Students, four, five and six. Data collection is done by observation, interviews, questionnaires, and documentary studies. Data analysis using correlational analysis with the product moment formula correlation technique. The results of hypothesis testing are as follows:

First, there is a positive and low influence between Religious Knowledge and Social Behavior of SDIT Nur El Qolam Students in Serang Banten. Furthermore, because the correlation coefficient $r=0.230$, the determination coefficient value obtained is $\mathrm{R} 2=0.053$ which means that $05.3 \%$ of the variance of Social Behavior of SD El Nur Nur Qolam Elementary School Students in Serang Banten through the regression equation: $\hat{\mathrm{Y}}=72.209+0.115 \mathrm{X} 1$ which is significant at the alpha level 0.05 .

Second, there is a positive and moderate effect between Emotional Intelligence and Social Behavior of SDIT Nur El Qolam Serang Banten Students. Furthermore, because the correlation coefficient $r=0.159$, the determination coefficient value obtained is $\mathrm{R} 2=0.025$ which means that $02.5 \%$ of the variance of Social Behavior of SDIT Nur El Qolam students in Serang Banten can be influenced by Emotional Intelligence through the regression equation: $\hat{Y}=74.602$ $+0.095 \mathrm{X} 2$ which significant at the alpha level of 0.05 .

Third, there is a positive and moderate influence between Religious Knowledge and Emotional Intelligence and Social Behavior of SDIT Nur El Qolam Serang Banten Students. Furthermore, because the correlation coefficient $r$ $=0.232$, the determination coefficient value of $\mathrm{R} 2=0.054$ can be obtained which means that $05.4 \%$ of the variance of Social Behavior of SD El Nur Nur Qolam Elementary School Students in Serang Banten can be influenced by Religious Knowledge and Emotional Intelligence through the regression equation: $\hat{Y}=$ $70,662+0.104 \mathrm{X} 1+0.024 \mathrm{X} 2$ which is significant at the alpha level of 0.05 .

This finding is expected to be able to make a positive contribution to the development of Religious Knowledge and Emotional Intelligence Towards Social Behavior SDIT Nur El Qolam Serang Banten in the existing generation and subsequent generations.

Keywords : Islamic Religious Knowledge, Emotional Intelligence and Social Behavior 


\section{Pendahuluan}

Pendidikan merupakan lembaga utama yang memainkan peranan penting dalam membangun dan menumbuh kembangkan peradaban. Maju mundurnya suatu peradaban ditentukan dengan pendidikan, bahkan peradaban dan kebudayaan umat manusia tidak akan pernah muncul tanpa ada lembaga yang mengarahkan manusia kearah tersebut, karna manusia terlahir kedunia tidak memilki daya dan ilmu yang dapat membuatnya berkembang lebih maju, maka pendidikanlah yang membangun daya dan pengetahuan tersebut dalam jiwa manusia.

Pendidikan mempunyai kedudukan yang sangat penting dalam pandangan islam yaitu sebagai mediator transfer pengetahuan dan ilmu, pendidikan mempunyai peran sebagai pemebntuk karakter dan akhlak manusia. Disamping itu, pendidikan dalam islam bertujuan pula untuk mempersiapkan geneasi yang kuat dan berkualitas, bukan generasi yang lemah dan tertinggal. Pada hakekatnya pendidikan merupakan suatu usaha yang dilakukan oleh manusia untuk meningkatkan taraf hidup yang lebih sempurna. Pendidikan merupakan kekuatan dinamis yang sangat berpengaruh terhadap perkembangan fisik, mental, etika dan seluruh aspek kehidupan manusia. Pendidikan juga merupakan salah satu faktor yang besar peranannya bagi kehidupan bangsa, karna pendidikan dapat mendorong maju dan mundurnya proses pembangunan bangsa. Madrasah sebagai sub system pendidikan nasional, tidak hanya diuntut dapat menyelenggarakan pendidikan dasar dan menengah yang berciri khas keagamaan, tetapi lebih jauh madrasah dituntut pula memainkan peran lebih sebagai basis dan benteng tangguh yang akan menjaga dan memperlakukan etika dan moral bangsa. $^{2}$

Dalam Undang-Undang No. 20 tahun 2003 tentang sistem pendidikan Nasional dinyatakan bahwa:

Pendidikan adalah usaha sadar untuk menyiapkan siswa melalui kegiatan bimbingan pengajaran dan latihan bagi peranannya dimasa datang. Kemajuan masyarakat modern dewasa ini, tidak mungkin dapat dicapai tanpa kehadiran institusi pendidikan sebagai organisasi yang menyelenggarakan pendidikan secara formal maupun informal. Kegiatan pendidikan yang berlangsung menempatkan institusi ini sebagai salah satu institusi sosial yang tetap eksis sampai sekarang. ${ }^{3}$

Proses pendidikan yang berlangsung, mempunyai ukuran dan standardisasi dalam menilai sejauh mana pengetahuan dan keterampilan siswa mampu mewujudkan nilai-nilai yang di peroleh melalui proses belajar mengajar. Siswa dalam kaitannya dengan pendidikan, merupakan salah satu komponen yang perlu di perhatikan, karena Siswa merupakan penerjemah terhadap dinamika ilmu pengetahuan, dan melaksanakan tugas mendalami ilmu pengetahuan tersebut. ${ }^{4}$

\footnotetext{
${ }^{1}$ Kadar M. Yusuf, Tafsir Tarbawi:Pesan-pesan Al-Quran tentang Pendidikan, Jakarta: Amzah, 2013, cet. 1, hal. 01.

${ }^{2}$ Husni Rahim, Arah Baru Pendidikan Islam di Indonesia, Jakarta: PT Logos Wacana Ilmu, 2001, cet. 1, hal. 32 .

${ }^{3}$ Syaparuddin \& Nasution, Manajemen Pembelajaran : QuantumTeaching, Jakarta: Raja Grafindo, 2000, hal. 105.

${ }^{4}$ S. Harahap, Penegakan Moral Akademik Didalam dan Luar Kampus, Jakarta: Raja Grafindo, 2006. hal.75.
} 
Pendidikan merupakan sesuatu yang penting didalam kehidupan, pendidikan adalah sebuah alat yang digunakan untuk membentuk karakter pada anak. Pedidikan hendaknya dilakukan sejak dini kepada anak. Orang tua dan guru selaku pendidik hendaknya tidak hanya memberikan pengetahuan kepada anak. Orang tua dan guru mempunyai kewajiban dalam mendidik karakter anak. Agar terciptanya karakter yang baik pada anak. Hal tersebut tidaklah mudah dilakukan membutuhkan proses yang cukup lama sehingga dapat menciptakan karakter anak yang baik dan berakhlak mulia. Karena anak merupakan aset yang menentukan kelangsungan hidup, kualitas dan kejayaan suatu bangsa di masa mendatang. Anak perlu dikondisikan agar dapat tumbuh dan berkembang secara optimal dan dididik sebaik mungkin agar di masa depan dapat menjadi generasi penerus yang berkarakter serta berkepribadian baik. Lembaga pendidikan formal (sekolah) diharapkan dapat menciptakan proses pembelajaran yang menyenangkan dan dapat mengembangkan potensi diri siswa agar memiliki kekuatan spiritual keagamaan, pengendalian diri, kepribadian, kecerdasan, akhlak mulia serta keterampilan yang diperlukan dirinya, masyarakat, bangsa dan negara. Keluarga merupakan lingkungan kehidupan yang dikenal anak untuk pertama kalinya, dan untuk seterusnya anak banyak belajar di dalam kehidupan keluarga.

Oleh karena itu peran, sikap dan perilaku orangtua dalam proses pengasuhan anak, sangat besar pengaruhnya dalam pembentukan dan perkembangan kepribadian anak. Dengan kehadiran seorang anak dalam keluarga, komunikasi dalam keluarga menjadi lebih penting dan intensitasnya harus semakin meningkat, artinya dalam keluarga perlu ada komunikasi yang baik dan sesering mungkin antara orang tua dengan anak. Cukup banyak persoalan yang timbul di masyarakat karena atau tidak adanya komunikasi yang baik dalam keluarga. Dalam kenyataannya, proses interaksi anak dengan orangtua tidak selalu sesuai dengan yang diharapkan dan tidaklah sesederhana yang kita bayangkan dan katakan.

Masa depan bangsa ditentukan oleh generasi muda yang cerdas. cerdas di sini bukan hanya IQ (Intellegences Quotien/ potensi intelektual) saja yang selama ini membudaya di masyarakat. Dan juga cerdas dalam EQ (Emotional Quontien) dan SQ (Spiritual Quontien). Dengan mendidik dan mencerdaskannya secara baik, berarti kita telah memberikan warisan yang terbaik bagi mereka bukan hanya nilai kuantitatif yang di dapat oleh para siswa, juga harus mendapatkan atau mencapai nilai kualitatif yaitu suatu nilai kepribadian yang di peroleh dari sebuah pembelajaran sehingga dapat di terapkan dalam kehidupan sehari-hari .

Berdasarkan observasi dilapangan terdapat ditemukannya suatu permasalahan yang tidak seimbang antara pengetahuan agama islam anak dan kecerdasaan emosional, sehingga dapat menyebabkan kurangnya sikap interaksi sosial yang dimiliki anak tersebut sehingga dapat mempengaruhi sikap sosial yang dimilikinya . permasalahan ini masih ditemukan di SDIT Nur El Qolam. Seperti diketahui banyak sekali nilai-nilai karakter yang masih kurang salah satunya adalah sikap saling membantu antara peserta didik, kurangnya kerja sama yang dimiliki saat belajar kelompok dan sikap sopan santun terhadap guru. Hal tersebut menjasi masalah yang serius sehingga perlu adanya perhatian khusus. Anak 
hendaknya memiliki pengetahuan agama islam yang cukup sehingga membantunya dalam meningkatkan kecerdasan emosi yang dimiliknya.

Dengan adanya kecerdasan emosi yang dimiliki oleh peserta didik hendaknya dapat meningkatkan sikap interaksi sosial yang dimilikinya. Anak dapat saling bekerja sama dengan baik dengan temannya saat belajar kelompok, saling menghargai antar teman dan pandai bersikap seperti menghormati guru dan bersikap sopan dalam kehidupan sehari-hari. Guru harusnya selaku pendidik tidak hanya memberikan ilmu kepada peserta didik, akan tetapi guru juga harus mampu mendidik anak tersebut dengan baik sehingga anak tersebut memiliki pribadi yang baik.

\section{Batasan dan Perumusan Masalah}

Berdasarkan penjelasan latar belakang masalah di atas, maka penulis membatasi masalah sebagai berikut:

1. Batasan Masalah

Untuk lebih efektif dan efisiennya penelitian ini, maka perlu dibatasi masalah dalam penelitian ini, dengan mempertimbangkan kemampuan, waktu, tenaga dan lainnya, maka penelitian ini di batasi pada hal-hal yang berkenaan dengan pengaruh pengetahuan keagamaan dan kecerdasan emosional terhadap prilaku sosial siswa kelas IV, V dan VI SDIT Nur El Qolam Serang Banten.

2. Rumusan Masalah

Berdasarkan Pembatasan masalah di atas, maka penulis dapat menetapkan beberapa rumusan pokok permasalahan yaitu :

a. Apakah ada pengaruh yang signifikan antara pengetahuan Keagamaan siswa terhadap prilaku sosial anak?

b. Apakah ada pengaruh yang signifikan antara kecerdasan Emosional siswa terhadap prilaku sosial anak?

c. Apakah ada pengaruh yang signifikan antara pengetahuan keagamaan dan kecerdasan emosional siswa terhadap prilaku sosial anak?

A. Landasan Teori

Dalam penelitian ini peneliti menggunakan jenis penelitian kuantitatif karena penelitian kuantitatif merupakan salah satu jenis penelitian yang spesifikasinya adalah sistematis, terencana, dan terstruktur dengan jelas sejak awal hingga pembuatan desain penelitiannya. Definisi lain menyebutkan penelitian kuantitatif adalah penelitian yang banyak menuntut penggunaan angka, mulai dari pengumpulan data, penafsiran terhadap data tersebut, serta penampilan dari hasilnya. Demikian pula pada tahap kesimpulan penelitian akan lebih baik bila disertai dengan gambar, table, grafik, atau tampilan lainnya.

Menurut Sugiyono, "metode penelitian kuantitatif dapat diartikan sebagai metode penelitian yang berlandaskan pada filsafat positivisme, digunakan untuk meneliti pada populasi atau sampel tertentu. Teknik pengambilan sampel pada umumnya dilakukan secara random, pengumpulan data menggunakan instrumen penelitian, analisis data bersifat kuantitatif/statistik dengan tujuan untuk menguji hipotesis yang telah ditetapkan"5. Metode kuantitatif sering juga disebut metode tradisional, positivistik, ilmiah/scientific dan metode discovery. Metode kuantitatif dinamakan metode tradisional, karena

\footnotetext{
${ }^{5}$ Suhardi Darmo, Analisi Data Variabel, Jakarta : Lembaga Penelitian UM. 2016, hal. 35.
} 
metode ini sudah cukup lama digunakan sehingga sudah mentradisi sebagai metode untuk penelitian. Metode ini disebut sebagai metode positivistik karena berlandaskan pada filsafat positivisme. Metode ini disebut sebagai metode ilmiah (scientific) karena metode ini telah memenuhi kaidah-kaidah ilmiah yaitu konkrit, empiris, obyektif, terukur, rasional dan sistematis. Metode ini juga disebut metode discovery karena dengan metode ini dapat ditemukan dan dikembangkan berbagai iptek baru. Metode ini disebut metode kuantitatif karena data penelitian berupa angka-angka dan analisis menggunakan statistik.

B. Pengertian Prilaku Sosial

Manusia sebagai makhluk sosial berarti manusia sebagai makhluk yang memiliki dimensi kebersamaan dengan orang lain. Teori Psikoanalisa misalnya, menyatakan bahwa manusia memiliki pertimbangan moral sosial (super ego) ketika dihadapkan pada pilihan-pilihan berperilaku. Sedangkan ilmu humaniora menjelaskan realitas sosial sebagai sebuah organisme hidup dalam bentuk teoriteori sosial tentang kehidupan manusia dalam bentuk masyarakat. ${ }^{6}$

Menurut teori prilaku sosial maupun teori perkembangan kognitif menyatakan bahwa perilaku yang ada pada diri seseorang berlandasan pada pertimbangan-pertimbangan moral kognitif. Selanjutnya, masalah aturan, norma, nilai, etika, akhlak dan estetika adalah hal-hal yang sering didengar dan selalu dihubungkan dengan konsep moral ketika seseorang akan menetapkan suatu keputusan perilakunya. ${ }^{7}$ Dalam diri setiap insan terdapat dua faktor utama yang sangat menentukan kehidupannya, yaitu fisik dan ruh. Pemahaman terhadap kedua faktor ini memberikan pengaruh yang sangat besar terhadap bagaimana seseorang berperilaku dalam realitas kehidupannya. Kedua faktor ini memiliki ruang dan dimensi yang berbeda. Jika yang pertama adalah sesuatu yang sangat mudah untuk diindra, tampak dalam bentuk perilaku, namun pada faktor yang kedua hanya dapat dirasakan dan menentukan terhadap baik buruknya suatu perilaku. ${ }^{8}$ Dalam hadits Nabi dipaparkan:

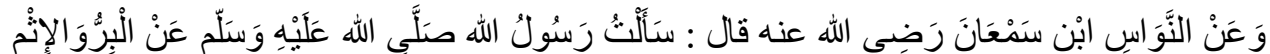

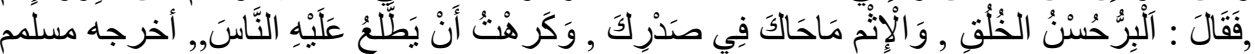

Dari An Nawwas Ibnu Sam'an ra. telah menceritakan, aku pernah bertanya kepada Rasulullah saw. mengenai kebajikan dan dosa, maka beliau menjawab: kebajikan adalah akhlak yang baik, dan dosa adalah sesuatu yang bergejolak di dadamu, sedangkan kamu tidak suka bila ada orang lain yang mengetahuinya. Hadits diriwayatkan oleh Muslim. ${ }^{9}$

Hadist diatas memberikan penjelasan kepada kita, tentang kebaikan dan dosa. Dimana setiap perilaku manusia tidak akan pernah lepas dari dua hal

\footnotetext{
${ }^{6}$ Abdul Latif, Pendidikan Berbasis Nilai Kemanusiaan, Bandung:Refika Aditama, 2009, hlm.4.

${ }^{7}$ Sjarkawi, Pembentukan Kepribadian Anak; Peran Moral Intelektual, Emosional dan Sosial sebagai Wujud Integritas Membangun Jati Diri, Jakarta: PT. Bumi Aksara, 2009, hlm. 26.

${ }^{8}$ Akh. Muwafik Saleh, Membangun Karakter dengan Hati Nurani, Jakarta: Erlangga, 2012 hlm. 103.

${ }^{9}$ Al Hafizd Ibnu Hadjar Al 'Asqalani, Bululughul Maram, terj. Hamim Thohari Ibnu M. Dailimi, Jakarta: Al Birr, 2002, hlm. 520
} 
tersebut. Disinilah fisik dan ruh saling bekerja. Perilaku manusia adalah suatu fungsi dari interaksi Antara individu dengan lingkungannya. ${ }^{10}$ Karena pada hakikatnya individu memiliki keunikan masing-masing yang membedakan satu dengan yang lain. Inilah yang disebut manusia sebagai makhluk individu. Seringkali orang menganggap sikap dan perilaku itu sama, padahal dalam berbagai literatur disebutkan bahwa sikap dan perilaku itu berbeda. Para peneliti klasik memang mengutarakan bahwa sikap itu sama dengan perilaku, sebelum adanya penelitian terkini yang membedakan antara sikap dan perilaku. Pada umumnya, sikap cenderung memprediksikan perilaku jika kuat dan konsisten, berdasarkan pengalaman langsung seseorang dan secara spesifik berhubungan dengan perilaku yang diprediksikan. ${ }^{11}$

Menurut Arthur S. Rober, "Prilaku atau tingkah laku adalah sebuah istilah yang sangat umum mencakup tindakan, aktivitas, respon, reaksi, gerakan, proses, operasi-operasi dsb. Singkatnya, respon apapun dari organisme yang bisa diukur".

Menurut Zimmerman dan Schank, Prilaku merupakan upaya individu untuk mengatur diri, menyeleksi dan memanfaatkan maupun menciptakan lingkungan yang mendukung aktivitasnya. Individu memilih, menyusun dan menciptakan lingkungan sosial dan fisik seimbang untuk mengoptimalkan pencapaian atas aktivitas yang dilakukan. ${ }^{13}$

Dapat disimpulkan bahwa prilaku sosial adalah aktivitas seseorang yang dapat diamati oleh orang lain atau instrument penelitian terhadap suatu perangsang atau situasi yang dihadapi yang berkaitan dengan sosial kemasyarakatan. Atau dapat dikatakan bahwa prilaku sosial merupakan tindakantindakan yang berkaitan dengan segala perbuatan yang secara langsung berhubungan atau dihubungkan dengan nilai-nilai sosial yang ada dalam masyarakat.

C. Faktor-Faktor yang Mempengaruhi Perilaku Sosial

Manusia merupakan makhluk hidup yang paling sempurna dibandingkan dengan makhluk hidup yang lainnya. Karena manusia memiliki akal sebagai pembeda dan merupakan kemampuan yang lebih dibanding makhluk yang lainnya. Akibat adanya kemampuan inilah manusia mengalami perkembangan dan perubahan baik dalam psikologis maupun fisiologis. Perubahan yang terjadi pada manusia akan menimbulkan perubahan pada perkembangan pada pribadi manusia atau tingkah lakunya. Pembentukan perilaku tidak dapat terjadi dengan sendirinya atau tanpa adanya proses tetapi Pembentukannya senantiasa berlangsung dalam interaksi manusia, dan berkenan dengan objek tertentu Ada dua faktor utama yang dapat mempengaruhi perilaku sosial seseorang, diantaranya:

1) Faktor internal

Faktor internal adalah faktor yang terdapat dalam diri manusia itu sendiri atau segala sesuatu yang telah dibawa oleh anak sejak lahir yaitu fitrah suci yang merupakan bakat bawaan. Faktor yang termasuk faktor internal, antara lain:

a) Kecerdasan emosional dan kecerdasan intelektual

\footnotetext{
${ }^{10}$ Veithzal Rivai, Kepemimpinan dan Perilaku Organisasi, Jakarta:Rajawali Press, 2009, hlm. 230.

${ }^{11}$ Robert A Baron, Social Psychology; Psikologi Sosial, terj. Ratna Djuwita, Jakarta: Penerbit Erlangga, 2003, ed. X jil. I, hlm. 130.

${ }^{12}$ Arthur S. Reber, The Penguin Dictionary of Psychology, terj. Yudi Santoso, Yogyakarta: Pustaka Pelajar, 2010, hlm. 110.

${ }^{13}$ Sebagaimana dikutip oleh M. Nur Ghufron, Teori-Teori Psikologi, Yogyakarta: Ar Ruzz Media, 2011, hlm. 19.
} 
Kecerdasan emosional sangat berperan penting dalam mempengaruhi perilaku sosial seseorang. Karena kecerdasan emosional sering kali disebut sebagai kecerdasan sosial yang mana dalam praktiknya selalu mempertimbangkan dengan matang segala aspek social yang menyertainya.

Dalam berperilaku sosial, kecerdasan emosional memerankan peran yang begitu penting. Adanya empati, memotivasi orang lain dan membina hubungan dengan orang lain merupakan aspek terpenting dalam kecerdasan emosional dan menjadi bagian yang tak dapat dipisahkan dengan faktor yang mempengaruhi perilaku sosial seseorang. Kecerdasan intelektual juga berperan penting dalam mempengaruhi perilaku sosial seseorang. Ingatan dan pikiran yang memuat ide-ide, keyakinan dan। pertimbangan yang menjadi dasar kesadaran sosial seseorang akan berpengaruh terhadap perilaku sosialnya. Ilmu pengetahuan merupakan faktor esensial dalam pendidikan. Keterlibatan ilmu pengetahuan manusia dalam memecahkan berbagai permasalahan sosial sangat mempengaruhi kualitas moral dan budi pekertinya. Ilmu pengetahuan dan teknologi sangat diperlukan untuk meningkatkan kualitas manusia. Disisi lain bila tidak terkendali, nilai-nilai yang luhur tersebut dapat menimbulkan kerugian diri sendiri.

b) Motivasi

Motivasi merupakan kekuatan penggerak yang membangkitkan aktivitas pada makhluk hidup dan menimbulkan tingkah laku serta mengarahkannya menuju tujuan tertentu. Dalam hal ini motivasi memerankan peranannya sebagai alasan seseorang melakukan sesuatu. Motivasi merupakan dorongan untuk melakukan sesuatu. Dalam perilaku, motivasi ini penting, karena perilaku sosial seseorang merupakan perilaku termotivasi.

c) Agama

Agama memegang peranan penting dalam mempengaruhi perilaku sosial seseorang. Seorang yang memiliki pemahaman agama yang luas, pasti juga memilki perilaku sosial yang baik. Karena pada hakikatnya, setiap agama mengajarkan kebaikan, khususnya agama Islam, sangat mendorong umatnya untuk memilki perilaku sosial.

2) Faktor eksternal

Faktor eksternal adalah segala sesuatu yang ada diluar manusia yang dapat mempengaruhi perkembangan kepribadian dan keagamaan seseorang. Adapun faktor-faktor tersebut adalah:

a) Lingkungan keluarga

Keluarga merupakan lingkungan yang pertama dan utama. Dalam keluarga itulah manusia menemukan kodratnya sebagai makhluk sosial. Karena dalam lingkungan itulah ia untuk pertama kali berinteraksi dengan orang lain. Kehidupan rumah tangga penuh dengan dinamika peristiwa. Dari sana anak-anak mendapatkan kecenderungan-kecenderungannya dan emosi-emosinya. Kalau iklim rumah penuh cinta, kasih saying, ketenangan dan keteguhan, maka anak akan merasa aman dan percaya diri, sehingga tampaklah pada dirinya kestabilan dan keteguhan. Tetapi kalau suasana rumah penuh dengan pertikaian dan hubungan-hubungan yang kacau diantara anggota-anggotanya, hal itu tercermin pada perilaku anak, sehingga kekacauan dan ketidakteguahan tampak pada perilakunya. 
Adaptasinya dengan dirinya dan dengan anggota masyarakat menjadi buruk. $^{14}$

b) Lingkungan masyarakat

Masyarakat adalah wadah hidup bersama dari individu-individu yang terjalin dan terikat dalam hubungan interaksi serta interelasi sosial. Dalam hidup manusia yang bermasyarakat senantiasa terjadi persesuaian antar individu melalui proses sosialisasi ke arah hubungan yang saling mempengaruhi. Lingkungan masyarakat juga tidak kalah penting dalam membentuk pribadi anak, karena dalam masyarakat berkembang berbagai organisasi sosial, kebudayaan, ekonomi, agama dan lain-lain. Perkembangan masyarakat itu juga mempengaruhi arah perkembangan hidup anak khususnya yang menyangku.

D. Pengertian Pengetahuan keagamaan

Menurut Kamus Besar Bahasa Indonesia Pusat Bahasa, Pengetahuan adalah segala sesuatu yang diketahui, berkenaan dengan hal materi pelajaran. ${ }^{15}$ Menurut Ahmad Tafsir, pengetahuan adalah semua yang diketahui sebagaimana menurut Al-Qurean, tatkala manusia dalam perut ibunya ia tidak tahu apa-apa. Kemudian lahir maka mulailah proses mengetahui sampai akhirnya dewasa. ${ }^{16}$ Menurut Supan Kusumamihardja, pengetahuan ialah pengenalan yang akrab tentang sesuatu yang berdasarkan pengalaman, misalnya pengetahuan tentang kota, sungai dan lain-lain. Pengetahuan lahir dari pengamatan yang cermat melalui panca indera, baik tanpa maupun dengan pertolongan alat ${ }^{17}$

Menurut Julian Baggini mengatakan pengetahuan adalah kepercayaan sejati yang dibenarkan sebagai tiga bagian tentang pengetahuan yaitu kepercayaan, fakta bahwa kepercayaan itu benar dan fakta bahwa seseorang bisa menyediakan cerita rasional untuk mewujudkan bahwa kepercayaan itu benar. ${ }^{18}$ Lebih lanjut menurut Jujun S. Suriasumantri mengatakan pengetahuan merupakan segenap apa yang diketahui manusia tentang suatu objek tertentu yang akan mempengaruhi prilaku, termasuk di dalamnya adalah ilmu yang merupakan bagian dari pengetahuan. ${ }^{19}$

Pendapat di atas dapat diambil kesimpulan bahwa pengetahuan adalah pengenalan yang menyeluruh terhadap suatu obyek, yang diperoleh dari pengalaman pengamatan yang cermat melalui panca indra dan bersifat subjektif maupun obyektif.

Sedangkan kata "agama" dalam Bahasa Indonesia berarti sama dengan kata "din" dalam Bahasa Arab, atau Bahasa Eropa sama dengan Religion (Inggris), la Religion ( Prancis ), De religie (Belanda) semua Agama perkataan "agama" berasal dari Bahasa Sansekerta yang berarti "tidak pergi, tetap ditempat, diwarisi turun temurun".Sedangkan pengertian Agama secara lebih luas yaitu kepercayaan kepada Tuhan yang dinyatakan dengan mengadakan hubungan

${ }^{14}$ Muhammad Sayyid Muhammad Az Za'balawi, Pendidikan Remaja antara Islam dan Ilmu Jiwa, Jakarta: Gema Insani Press, 2007,hlm. 159.

${ }^{15}$ Departemen Pendidikan Nasional, Kamus Besar Bahasa Indonesia Pusat Bahasa, Jakarta: PT. Gramedia Pustaka Utama, 2008, hlm. 1377

${ }^{16}$ Ahmad Tafsir, Filsafat Ilmu, Bandung: PT Remaja Rosdakarya, 2004, hlm. 4.

${ }^{17}$ Supan Kusumamihardja, Studi Islamica,Jakarta: Girimukti Pasaka, 1985. hlm.9.

${ }^{18}$ Julian Baggini, Lima Tema Utama Filsafat, Jakarta: Teraju, 2004,hal. 28

${ }^{19}$ Jujun S. Suriasumantri, filsafat Ilmu sebuah pengantar popular, Jakarta: Pustaka Sinar Harapan,2005, hal. 104 
dengan Dia melalui upacara, penyembahan dan permohonan dan membentuk sikap hidup manusia menurut atau berdasarkan ajaran agama itu. ${ }^{20}$

Menurut Elizabeth K. Nottingham dalam buku Jalaludin, agama adalah gejala yang begitu sering "terdapat di mana-mana", dan agama berkaitan dengan usaha-usaha manusia untuk mengukur dalamnya makna dari keberadaan diri sendiri dan keberadaan alam semesta. Selain itu agama dapat membangkitkan kebahagiaan batin yang paling sempurna dan juga perasaan takut dan ngeri. Meskipun perhatian tertuju kepada adanya suatu dunia yang tak dapat dilihat (akhirat), namun agama melibatkan dirinya dalam masalah-maslaah kehidupan sehari-hari di dunia ${ }^{21}$

Jadi kesimpulan di atas yang dimaksud pengetahuan agama islam yaitu segala apa yang diketahui tentang kepercayaan peribadatan kepada Allah, yang menyangkut hubungan dengan Allah melalui peribadatan dan permohonan serta seluruh ajaran-ajaran yang terdapat dalam agama tersebut. Pengetahuan Agama Islam yang dimiliki manusia akan menjadi reverensi yang memperluas pandangannya dalam tindakan. Bagi orang Islam, pengetahuan ini menunjukkan seberapa tingkat pengetahuan dan pemahaman seorang muslim terhadap ajaran agamanya, terutama mengenai ajaran pokok agama yang termuat dalam kitab suci Al-Qur'an dan Hadits.

E. Pengertian Kecerdasan Emosional

Kata kecerdasan menurut Bahasa Latin dikenal sebagai Intelligentia. Dalam bahasa Inggris masing-masing diterjemahkan sebagai intellect dan intelligence. Intelligence, yang dalam bahasa Indonesia kita sebut sebagai inteligensi (kecerdasan), semua berarti penggunaan kekuatan intelektual secara nyata, tetapi kemudian diartikan sebagai suatu kekuatan lain ${ }^{22}$.

Menurut gardner sebagaimana yang telah dikutip oleh Meilania, manusia itu, siapa saja kecuali cacat atau punya kelainan otak sedikitnya memiliki 8 kecerdasan ${ }^{23}$. Kecerdasan manusia saat ini tidak hanya dapat diukur dari kepandainnya menguasai metematika atau menggunakan bahasa. Ada banyak kecerdasan yang dapat diidentifikasi di dalam diri manusia. Berikut ini 8 macam kecerdasan yaitu:

a) Kecerdasan linguistik adalah kemampuan menggunakan kata-kata secara efektif, baik untuk memengaruhi maupun memanipulasi. Dalam kehidupan sehari-hari kecerdasan linguistik bermanfaat untuk: berbicara, mendengarkan, membaca dan menulis. Ciri-ciri orang yang memiliki kecerdasan ini umumnya Seorang anak yang mempunyai kecerdasan linguistik memiliki keperibadian yaitu peka terhadap bahasa, dapat berbicara dengan teratur dan sistematis, memiliki penalaran yang tinggi. Disamping itu juga mampu mendengarkan, membaca dan menulis, lancer dalam mengucapkan kata-kata dan suka bermain kata-kata dan memiliki perbendaharaan kata yang kuat

b) Kecerdasan logis-matematis yaitu melibatkan keterampilan mengolah angka atau kemahiran menggunakan logika atau akal sehat. Dalam kehidupan seharihari bermanfaat untuk menganalisa laporan keuangan, mamahami perhitungan utang nasional, atau mencerna laporan sebuah penelitian. Ciri-ciri orang yang

\footnotetext{
${ }^{20}$ Mohammad daud ali, Pendidikan Agama Islam, jakarta: Raja Grafindo Persada, 2006, cet. II, hlm. 40.

${ }^{21}$ Jalaludin, Psikologi Agama, Jakarta : PT. RajaGrafindo Persada, 2012, hlm. 317.

${ }^{22}$ Hamzah B. Uno, Orientasi Baru Dalam Psikologi Pembelajaran, Jakarta: PT Bumi Aksara, 2006, hal. 58

${ }^{23}$ Meilania, Diktat HCD Multiple Intelagences, (Salatiga: CV. Pustaka Ilmu, 2006), hal 2
} 
memiliki kecerdasan ini umumnya memilki ciri-ciri kepribadian yaitu anak suka berfikir abstrak dan keakuratan, menikmati tugas hitung menghitung, memecahkan soal-soal dan komputer dan suka melakukan penelitian dengan cara logis, catatan tersusun rapid an sistematis.

c) Kecerdasan visual dan spasial yaitu melibatkan kemampuan seseorang untuk memisualisasikan gambar di dalam kepala (dibayangkan) atau menciptakannya dalam bentuk dua atau tiga dimensi. Kecerdasan ini sangat di butuhkan dalam berbagai aspek kehidupan sehari-hari, misalnya: saat menghiasi rumah atau merancang taman, menggambar atau melukis, menikmati karya seni. Ciri-ciri orang yang memiliki kecerdasan ini umumnya adalah anak dapat berpikir dengan menciptakan sketsa atau gambar, mudah sekali membaca peta dan diagram, mudah ingat bila melihat gambar, memiliki cita warna tinggi dan mampu menggunakan panca indra untuk melukiskan sesuatu.

d) Kecerdasan musik yaitu melibatkan kemampuan menyanyikan lagu, mengingat melodi musik, mempunyai kepekaan akan irama, atau sekedar menikmati musik. Manfaat dari kecerdasan ini dapat dirasakan dalam banyak hal dalam kehidupan sehari-hari, misalnya: saat menyanyi, memainkan alat musik, menikmati musik di TV/ Radio. Ciri-ciri orang yang memiliki kecerdasan ini umumnya adalah anak peka terhadap nada, irama dan warna suara. Peka terhadap nuansa emosi suatu musik dan peka terhadap perubahan musik yang bervariasi dan biasanya sangat spiritual.

e) Kecerdasan interpersonal yaitu melibatkan kemampuan untuk memahami dan bekerja dengan orang lain. Kecerdasan ini melibatkan banyak halnya; kemampuan berempati, kemampuan memanipulasi, kemampuan "membaca orang", kemampuan berteman. Ciri-ciri orang yang memiliki kecerdasan ini umumnya adalah anak ahli dalam berunding, pintar bergaul dan mampu membaca niat orang lain serta menikmati saat-saat bersama orang lain. Memiliki banyak teman, pintar berkomunikasi, suka dengan kegiatan-kegiatan kelompok, gemar bekerjasama dan menjadi mediator serta pandai membaca situasi.

f) Kecerdasan intrapersonal adalah kecerdasan memahami diri sendiri, kecerdasan untuk mengetahui "siapa diri saya sebenarnaya", untuk mengetahui "apa kekuatan dan kelemahan saya". Ini juga merupakan kecerdasan untuk bisa merenungkan tujuan hidup sendiri dan untuk mempercayai diri sendiri. Ciri-ciri orang yang memiliki kecerdasan ini umumnya adalah anak peka terhadap nilai-nilai yang dimiliki, sangat memahami diri, sadar betul emosi dirinya, peka terhadap tujuan hidupnya, mampu mengembangkan kepribadiannya, bias memotivasi diri sendiri, sangat sadar akan kekuatan dan kelemahannya.

g) Kecerdasan kinestetik adalah kecerdasan seluruh tubuh dan juga kecerdasan tangan. Dalam dunia sehari-hari kecerdasan ini sangat dibutuhkan, misalnya: membuka tutup botol, memasang lampu di rumah, memperbaiki mobil, olahraga, dan berdansa. Ciri-ciri orang yang memiliki kecerdasan ini umumnya adalah anak dapat bersikap rileks, suka olaraga fisik dan suka menyentuh. Anak ahli bermain peran, belajar dengan bergerak-gerak dan berperan serta dalam proses belajar. Selain itu anak juga sangat peka dengan kondisi lingkungan fisik, gerak-gerik tubuh terlatih dan terkendali dan suka bermain dengan sesuatu benda sambil mendengarkan orang lain berbicara dan sangat berminat dengan bidang mekanik. 
h) Kecerdasan naturalis yaitu melibatkan kemampuan mengenali bentuk bentuk alam sekitar kita. Dalam kehidupan sehari-hari kecerdasan itu sangat dibutuhkan untuk; berkebun, berkemah, atau melakukan proyek ekologi. Ciriciri orang yang memiliki kecerdasan ini umumnya adalah anak suka dengan alam sekitar, lebih senang berada di alam terbuka daripada di ruangan dan suka berpetualang menjelajah hutan. Anak biasa marah besar jika ada orang membatai binatang langka, merusak dan membakar hutan, mencemari laut dan sungai sehingga menimbulkan kematian flora dan fauna serta lebih suka mengkonsumsi obat dan jamu tradisional daripada pabrik. Anak juga lebih senang menggunakan bahan yang alami dan tidak menimbulkan polusi lingkungan.

Emosi berasal dari kata emotus atau emovere, yang artinya mencerca. Maksudnya, sesuatu yang mendorong terhadap sesuatu. Seperti: emosi karena ada unsur gembira, hal ini mendorong individu untuk melakukan perubahan pada suasana hati, sehingga menyebabkan tertawa. Atau sebaliknya, marah menunjukkan suasana hati untuk melakukan penyerangan atau mencerca terhadap sesuatu yang menyebabkan seseorang marah. ${ }^{24}$ Secara harfiah menurut Oxfortd English Dictionary mendefinisikan emosi sebagai setiap kegiatan atau pergolakan pikiran, perasaan, nafsu, setiap keadaan mental yang hebat atau meluap-luap. ${ }^{25}$ Dalam kamus Besar Bahasa Indonesia diartikan bahwa emosi adalah luapan perasaan yang berkembang dan surut dalam waktu singkat ${ }^{26}$

Menurut Ginanjar, emosi dapat dipandang pula sebagai bahan bakar yang tidak tergantikan bagi otak agar mampu melakukan penalaran yang tinggi. Selain itu, emosi menyulut kreativitas, kolaborasi, inisiatif dan transformasi, sedangkan penalaran logir berfungsi untuk mengantisipasi dorongan-dorongan keliru, untuk kemudian menyelaraskannya dengan proses kehidupan dengan sentuhan manusiawi. $^{27}$

Menurut Nyayu Khadijah Definisi emosi dirumuskan secara bervariasi oleh para psikolog, dengan orientasi teoritis yang berbeda-beda. William James mendefinisikan emosi sebagai keadaan budi rohani yang menampakkan dirinya dengan suatu perubahan yang jelas pada tubuh. Goleman mendefinisikan emosi sebagai suatu keadaan biologis dan psikologis dan serangkaian kecenderungan untuk bertindak. ${ }^{28}$

Menurut Chaplin yang dikutif oleh Mohamad Ali dan Mohamad Asrori Dictionary of Psychology mendefinisikan emosi sebagai suatu keadaan yang terangsang dari organisme mencakup perubahan-perubahan yang disadari, mendalam sifatnya dari perubahan perilaku. ${ }^{29}$ Emosi biasanya dibangkitkan oleh peristiwa eksternal dan reaksi emosional yang ditunjukkan pada peristiwa. Emosi kadang-kadang dibangkitkan oleh motivasi, sehingga antara emosi dan motivasi terjadi hubungan interaktif.

\footnotetext{
${ }^{24}$ Romlah, Psikologi Pendidikan, Malang: Universitas Muhammadiyah Malang, 2010, hlm. 65 .

${ }^{25}$ Yatim Riyanto, Paradigma Baru Pembelajaran: sebagai Referensi bagi Guru/Pendidik dalam Implementasi Pembelajaran yang Efektif dan Berkualitas, Jakarta: Kencana, 2010, hlm 252.

${ }^{26}$ DEPDIKNAS, Kamus Besar Bahasa Indonesia. Jakarta: Balai Pustaka, 2007, hlm. 298.

${ }^{27}$ Ary Ginanjar Agustian, ESQ (Emotional Spiritual Quotient): Rahasia Sukses

Membangun Kecerdasan Emosi dan Spiritual (Jakarta: Arga, 2005), h. 280.

${ }^{28}$ Nyayu Khadijah, Psikologi Pendidikan, Jakarta: Rajawali Pers, 2014, hlm. 137-138.

${ }^{29}$ Mohammad Ali, Mohammad Asrori, Psikologi Remaja Perkembangan Peserta Didik, (Jakarta: PT Bumi Aksara, 2008), hlm. 62.
} 
Menurut Daniel Goleman yang dikutif oleh Mohamad Ali dan Mohamad Asrori mengidentifikasi sejumlah kelompok emosi, yaitu sebagai berikut: ${ }^{30}$

a) Amarah, di dalamnya meliputi brutal, mengamuk, benci, jengkel, kesal hati, tersinggung, bermusuhan, tindak kekerasan.

b) Kesedihan, di dalamnya meliputi sedih, muram, kesepian, putus asa, dan depresi.

c) Rasa Takut, didalamnya meliputi cemas, takut, gugup, khawatir, sedih, tidak tenang, dan panik

d) Kenikmatan, di dalamnya meliputi bahagia, senang, terhibur, bangga, terpesona, puas.

e) Cinta, didalamnya meliputi penerimaan, persahabatan, kepercayaan, kebaikan hati, rasa dekat, bakti, hormat, kasmaran, dan kasih sayang.

f) Terkejut, di dalamnya meliputi terkesiap, terkejut

g) Jengkel, di dalamnya meliputi hina, jijik, muak, benci, tidak suka

h) Malu, di dalamnya meliputi malu hati, hina, aib.

i) Beberapa tokoh yang menyebutkan macam-macam emosi, antara lain Descrates. Menurutnya, emosi terbagi atas: desire (hasrat), hate (benci), sorrow (sedih/duka), wonder (heran), love (cinta), dan joy (kegembiraan). Sedangkan JB Watson mengemukakan tiga macam emosi, yaitu: fear (ketakutan), rage (kemarahan), love (cinta). ${ }^{31}$

\section{Pembahasan Hasil Penelitian}

Berdasarkan data yang diperoleh dari hasil penelitian kemudian diolah dengan menggunakan perangkat lunak SPSS for windows versi 21, dapat dijadikan sebagai dasar untuk menjawab hipotesis yang diajukan yaitu adanya "Pengaruh pengetahuan agama dan kecerdasan emosional terhadap perilaku sosial anak" baik secara sendiri-sendiri maupun simultan (bersama-sama). Beberapa faktor yang mempengaruhi perilaku sosial anak, maka beberapa faktor yang dikemukakan di atas merupakan faktor-faktor yang baik secara langsung maupun tidak langsung memiliki pengaruh dengan terhadap perilaku sosial anak.

Atas dasar kerangka di atas, maka dapat di gambarkan dalam sebuah bagan korelasi sebagai berikut:

Gambar 4.8

Kostelasi antar Variabel

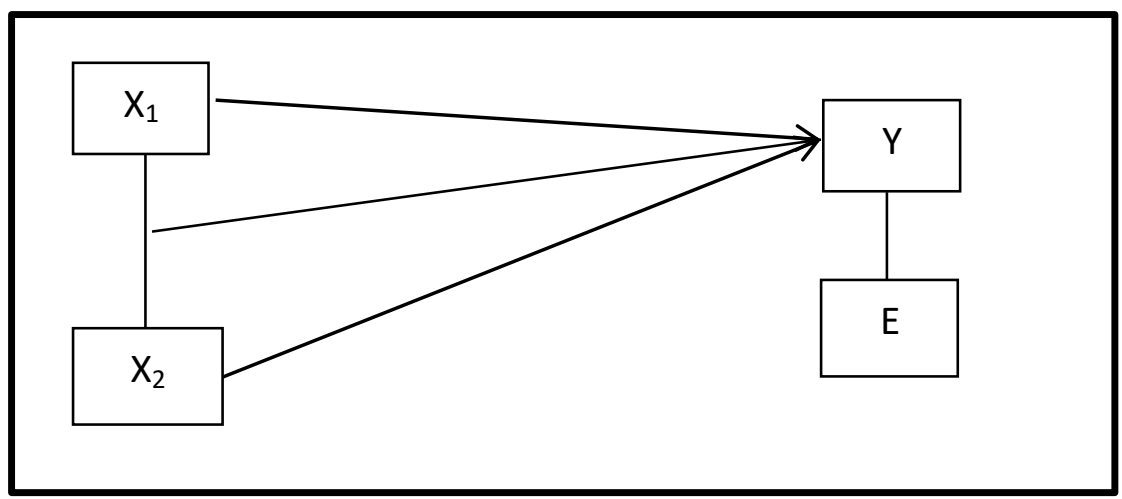
.... hlm. 63 .

${ }^{30}$ Mohammad Ali, Mohammad Asrori, Psikologi Remaja Perkembangan Peserta Didik,

${ }^{31}$ Rohmalina Wahab, Pisikologi Belajar, Jakarta: Rajawali Pres, 2016, hal. 159 


$$
\begin{array}{ll}
\mathrm{Y} & : \text { Perilaku Sosial } \\
\mathrm{X}_{1} & : \text { Pengetahuan Agama } \\
\mathrm{X}_{2} & : \text { Kecerdasan Emosional } \\
\mathrm{E} & : \text { Hipotesa }
\end{array}
$$

Berdasarkan rekapitulasi hasil pengujian hipotesis sebagaimana terlihat pada tabel 4.5.12 di atas, maka dapat dilakukan pembahasan sebagai berikut: Secara keseluruhan temuan dalam penelitian ini, dapat dibahas dengan cara mengkonfirmasi terhadap teori-teori yang sudah ada, sebagaimana telah dikemukakan pada Bab II di atas, yaitu:

Pertama, hasil penelitian ini sejalan dan mendukung teori yang disampaikan oleh bahwa pengetahuan agama yang dimiliki siswa akan mempengaruhi kecerdasan emosional yang dimiliki oleh anak, perkembangan kecerdasan emosional akan mempengaruhi perilaku sosial anak Pengetahuan agama merupakan suatu yang penting di dalam proses kehidupan, hal ini karena di dalam pengetahuan agama khususnya individu karena dengan pengetahuan agama yang cukup anak akan mampu menerapkannya kedalam kehiduoan sehari-hari karena itu pengetahuan tentang agama perlu ditingkatkan agar mendukung perilaku manusia supaya berbuat baik sesuai dengan ajaran agama. Jelaslah bahwa pengetahuan agama menjadi dasar utama bagi manusia. Dengan saling menghormati, saling membutuhkan, saling mengerti, dan menghargai hak dan kewajiban masing-maisng. Hal ini sesuai Firman Allah SWT, sebagai berikut :

Hai orang-orang beriman apabila kamu dikatakan kepadamu: "Berlapang-lapanglah dalam majlis", maka lapangkanlah niscaya Allah akan memberi kelapangan untukmu. dan apabila dikatakan: "Berdirilah kamu", maka berdirilah, niscaya Allah akan meninggikan orang-orang yang beriman di antaramu dan orang-orang yang diberi ilmu pengetahuan beberapa derajat. Dan Allah Maha mengetahui apa yang kamu kerjakan.(Al-Qur'an, Surat Al-Mujadalah Ayat 11).

Kedua, memperhatikan Pengaruh Antara Pengetahuan Agama $\left(\mathrm{X}_{1}\right)$ dan Kecerdasan Emosional $\left(\mathrm{X}_{2}\right)$ dengan Perilaku Sosial (Y)

Hipotesis nol (H0) yang menyatakan tidak terdapat pengaruh positif antara Pengetahuan Agama $\left(\mathrm{X}_{1}\right)$ dan Kecerdasan Emosional $\left(\mathrm{X}_{2}\right)$ secara bersama-sama dengan perilaku sosial (Y) melawan hipotesis alternatif (HI) yang menyatakan terdapat pengaruh positif antara pengetahuan agama $\left(\mathrm{X}_{1}\right)$ dan kecerdasan emosional $\left(\mathrm{X}_{2}\right)$ secara bersama-sama dengan perilaku sosial $(\mathrm{Y})$, pengujian tersebut dengan menggunakan teknik analisis regresi dan korelasi sederhana.

Dari hasil perhitungan analisis regresi linear berganda antara pengetahuan agama dan kecerdasan emosional dengan perilaku sosial diperoleh persamaan regresi yaitu $\hat{Y}=70,662+0,104 X_{1}+0,024 X_{2}$. Dari persamaan tersebut maka dapat diartikan bahwa satu-satuan skor perilaku sosial akan dipengaruhi oleh pengetahuan agama sebesar 0,104 dan kecerdasan emosional 0,024 pada konstanta 70,662 .

Hasil koefesien regresi untuk variabel pengetahuan agama sebesar 0,104. Harga koefesien regresi yang bertanda positif menunjukkan bahwa pengaruh pengetahuan agama dengan perilaku sosial pengaruh positif dan lemah, yang 
artinya setiap terjadi kenaikan satu skor pengetahuan agama, maka akan diikuti dengan meningkatnya perilaku sosial 0,104 .

Harga koefesien regresi untuk variable kecerdasan emosional sebesar 0,024. Harga koefesien regresi yang bertanda positif menunjukkan bahwa pengaruh kecerdasan emosional dengan perilaku sosial ada pengaruh positif dan lemah, yang artinya setiap terjadi kenaikan satu skor kecerdasan emosional, maka akan diikuti dengan meningkatnya perilaku sosial sebesar 0,024 .

\section{Kesimpulan} berikut:

Dari hasil analisis yang telah dilakukan, dapat diambil kesimpulan sebagai

1. Pengetahuan Agama mempunyai pengaruh yang positif terhadap Perilaku Sosial dengan tingkat interpetasi yaitu 0, 230 atau prosentase 23,0 \%. Hasil koefesien regresi untuk variabel pengetahuan agama sebesar 0,104 . koefesien regresi yang bertanda positif menunjukkan bahwa pengaruh pengetahuan agama dengan perilaku sosial ada pengaruh positif dan lemah, yang artinya setiap terjadi kenaikan satu skor pengetahuan agama, maka akan diikuti dengan mempengaruhi perilaku sosial sebesar 0,104 atau prosentase 10,4 $\%$.

2. Kecerdasan Emosional mempunyai pengaruh yang positif terhadap perilaku sosial dengan tingkat interpetasi yaitu 0,159 atau prosentase $15,9 \%$. Hasil koefesien regresi untuk variabel kecerdasan emosional sebesar 0,024. Harga koefesien regresi yang bertanda positif menunjukkan bahwa pengaruh kecerdasan emosional dengan perilaku sosial ada pengaruh positif dan lemah, yang artinya setiap terjadi kenaikan satu skor kecerdasan emosional, maka akan diikuti dengan mempengaruhi perilaku sosial sebesar 0,024 .

3. Dari hasil regresi linier sederhana pengaruh antara pengetahuan agama dan kecerdasan emosional dengan prilaku sosial menghasilkan nilai sebesar 0,128 poin yang artinya pengetahuan agama dan kecerdasan emosional naik satu poin atau satu skor diikuti dengan kenaikan prilaku sosial sedangkan kontribusi variabel pengetahuan agama dan kecerdasan emosional terhadap prilaku sosial sebesar $05,4 \%$ dan 94,6\% dipengaruhi oleh faktor lainnya.

\section{Implikasi Hasil Penelitian}

1. Upaya meningkatkan dengan Perilaku Sosial melalui pengetahuan agama. Pengetahuan agama islam yaitu segala apa yang diketahui tentang kepercayaan peribadatan kepada Allah, yang menyangkut hubungan dengan Allah melalui peribadatan dan permohonan serta seluruh ajaran-ajaran yang terdapat dalam agama tersebut. Pengetahuan Agama Islam yang dimiliki manusia akan menjadi reverensi yang memperluas pandangannya dalam tindakan. Bagi orang Islam, pengetahuan ini menunjukkan tingkat pengetahuan dan pemahaman seorang muslim terhadap ajaran agamanya, terutama mengenai ajaran pokok agama yang termuat dalam kitab suci Al-qur'an dan Hadits.

Dalam pengetahuan agama juga terdapat sifat-sifat terpuji yang harus dimiliki, sifat-sifat tersebut berkaitan erat dengan hubungan 
sosial manusia, sesuai yang diajarkan dengan ajaran agama diantaranya : amanah, ikhlas, sabar, jujur, tawadhu, saling mengingatkan, silaturahmi, menepati janji, menjaga ucapan, ukhuwah, memaafkan. Dengan memiliki sifat terpuji seseorang akan mudah diterima dilingkungan masyarakat, mempunyai perilaku sosial yang baik. Oleh karena itu perlu adanya peningkatan pengetahuan yang di berikan guru kepada siswa agar pengetahuan agama yang dimiliki siswa dapat meningkat sehingga dapat mempengaruhi perilaku sosial siswa kerarah yang lebih baik.

2. Upaya menigkatkan perilaku sosial melalui kecerdasan emosional. kecerdasan emosional kemampuan seperti kemampuan untuk memotivasi diri sendiri dan bertahan menghadapi frustasi mengendalikan dorongan hati dan tidak berlebih-lebihan kesenangan mengatur suasana hati dan menjaga agar beban setres tidak melumpuhkan kemampuan berfikir berempati dan berdoa. Kecerdasan emosional merupakan konsep baru sampai sekarang belum ada yang dapat mengemukakan dengan tepat sejauh mana variasi yang ditimbulkannya atas perjalanan hidup seseorang. Tetapi, data yang ada mengisyaratkan bahwa kecerdasan emosional dapat sama ampuhnya dan terkadang lebih ampuh daripada IQ. Meskipun ada orang-orang yang mengatakan bahwa IQ tidak dapat banyak diubah oleh pengalaman atau pendidikan, kemampuan emosional yang penting itu benar-benar dapat dipelajari dan dikembangkan pada anak-anak apabila kita berusaha untuk mengajarkannya. Banyak bukti memperlihatkan bahwa orang yang secara emosional cakap yang mengetahui dan menangani perasaan mereka sendiri dengan baik, dan yang mampu membaca dan menghadapi perasaan orang lain dengan efektif memiliki keuntungan dalam setiap bidang kehidupan. Seseorang yang memiliki kecerdasan emosional akan mampu : Mengenali dan mengendalikan emosi diri sendiri, mengelola emosi dengan baik, memotivasi diri sendiri, mengenali emosi orang lain, memnina hubungan yang baik dengan orang lain.

Dengan memiliki kecerdasan emosi yang baik sesrorang akan memiliki perilaku yang baik sehingga dalam perilaku sosial akan mampu menyesuaikan diri terhadap lingkungannya, mampu di terima orang banyak dan mudah bergaul, selain itu orang yang memiliki kecerdasan emosional akan mampu mengendalikan diri dari perbuatan yang kurang baik yang dapat merugikan orang lain kecerdasan emosional sangat penting dimiliki oleh anak sejak dini agar dapat membentuk perilaku sosial baik. Oleh karena itu hendaknya guru dalam pembelajaran tidak hanya mementingkan IQ, tetapi juga mementingkan Kecerdasan emosional yang dimiliki siswa.

3. Upaya peningkatan perilaku sosial dengan pengetahuan agama dan kecerdasan emosional. Dengan melihat banyaknya dampak positif yang diberikan pengetahuan agama dan kecerdasan emosional sangat baik di kembangkan sejak dini. Seseorang harusnya mempunyai pengetahuan agama yang mencukupi dalam menjalini kehidupan sehingga akan mampu mengerti apa yang boleh dilakukan dan tidak boleh dilakukan. Dengan memiliki pengetahuan agama akan mampu mengebangkan kecerdasan emosional yang dimilki. Karena kecerdasaan emosional yang baik akan mampu membantu siswa dapat beradaptasi dengan lingkungannya. 
Oleh karena itu perlu adanya pemahaman orang tua dan guru didalam proses mendidik anak dalam usaha peningkatan perilaku sosial anak, dimulai dari memberikan pengetahuan agama yang cukup diberikan, dan menumbuh kembangkan kecerdasan emosional yang dimilikinya. Perlu usaha yang mendalam, selain faktor tersebut ada banyak pula yang mempengaruhi perilaku sosial seperti Lingkungan keluarga merupakan lingkungan yang pertama dan utama. Dalam keluarga itulah manusia menemukan kodratnya sebagai makhluk sosial. Karena dalam lingkungan itulah ia untuk pertama kali berinteraksi dengan orang lain. Kehidupan rumah tangga penuh dengan dinamika peristiwa. Dari sana anakanak mendapatkan kecenderungan-kecenderungannya dan emosi-emosinya. Lingkungan masyarakat adalah wadah hidup bersama dari individuindividu yang terjalin dan terikat dalam hubungan interaksi serta interelasi sosial. Dalam hidup manusia yang bermasyarakat senantiasa terjadi persesuaian antar individu melalui proses sosialisasi ke arah hubungan yang saling mempengaruhi. Lingkungan masyarakat juga tidak kalah penting dalam membentuk pribadi anak, karena dalam masyarakat berkembang berbagai organisasi sosial, kebudayaan, ekonomi, agama dan lain-lain. Perkembangan masyarakat itu juga mempengaruhi arah perkembangan hidup anak.

Sehingga dapat disimpulkan pengetahuan agama dan kecerdasan emosional sangat berperan penting dalam perilaku sosial anak. Anak akan mempunyai perilaku sosial yang baik apabila anak tersebutu mempunyai pengetahuan agama yang cukup dan kecerdasaan emosional yang baik.

\section{Daftar Pustaka}

Latif Abdul, Pendidikan Berbasis Nilai Kemanusiaan, Bandung:Refika Aditama, 2009, hlm. 4.

Tafsir Ahmad, Filsafat Ilmu, Bandung: PT Remaja Rosdakarya, 2004, hlm. 4.

Thib Ahmad Raya dan Siti Musdah Mulia, Menyelami Seluk Beluk Ibadah Dalam Islam, Bogor: Kencana, 2003, hlm.23

Akh. Muwafik Saleh, Membangun Karakter dengan Hati Nurani, Jakarta: Erlangga, 2012 hlm. 103.

Al Hafizd Ibnu Hadjar Al 'Asqalani, Bululughul Maram, terj. Hamim Thohari Ibnu M. Dailimi, Jakarta: Al Birr, 2002, hlm. 520

Arthur S. Reber, The Penguin Dictionary of Psychology, terj.Yudi Santoso, Yogyakarta: Pustaka Pelajar, 2010, hlm. 110.

Departemen Agama Republik Indonesia, Al-Qur'an dan Terjemahannya, hlm.50

Departemen Pendidikan dan Kebudayaan, Kamus Besar Bahasa Indonesia, hlm. 20.

Departemen Pendidikan Nasional, Kamus Besar Bahasa Indonesia Pusat Bahasa, Jakarta: PT. Gramedia Pustaka Utama, 2008, hlm. 1377

DEPDIKNAS, Kamus Besar Bahasa Indonesia. Jakarta: Balai Pustaka, 2007, hlm. 298

Djamaludin Ancok dan Fuat Nashori Suroso, Psikologi Islami, Yogyakarta: Pustaka Pelajar, 1994, hlm. 79 
Hamzah B. Uno, Orientasi Baru Dalam Psikologi Pembelajaran, Jakarta: PT Bumi

Husni Rahim, Arah Baru Pendidikan Islam di Indonesia, Jakarta: PT Logos Wacana Ilmu, 2001, cet. 1, hal. 32.

Jalaludin, Psikologi Agama, Jakarta : PT. RajaGrafindo Persada, 2012, hlm.317.

Jujun S. Suriasumantri, filsafat Ilmu sebuah pengantar popular, Jakarta: Pustaka Sinar Harapan,2005, hal. 104

Julian Baggini, Lima Tema Utama Filsafat, Jakarta: Teraju, 2004, hal. 28.

Kadar M. Yusuf, Tafsir Tarbawi:Pesan-pesan Al-Quran tentang Pendidikan, Jakarta: Amzah, 2013, cet. 1, hal. 01.

Meilania, Diktat HCD Multiple Intelagences, (Salatiga: CV. Pustaka Ilmu, 2006), hal. 2

Mohammad Ali, Mohammad Asrori, Psikologi Remaja Perkembangan Peserta Didik, (Jakarta: PT Bumi Aksara, 2008), hlm. 62.

Mohammad Ali, Mohammad Asrori, Psikologi Remaja Perkembangan Peserta Didik, .... hlm. 6

Mohammad daud ali, Pendidikan Agama Islam, jakarta: Raja Grafindo Persada, 2006, cet. II, hlm . 40.

Muhammad Sayyid Muhammad Az Za'balawi, Pendidikan Remaja antara Islam dan Ilmu Jiwa, Jakarta: Gema Insani Press, 2007, hlm. 159

Nyayu Khadijah, Psikologi Pendidikan, Jakarta: Rajawali Pers, 2014, hlm. 137138

Oneng Nurul Bariyah, Materi Hadits tentang Islam, hukum, ekonomi, sosial dan lingkunga), Jakarta: Kalam Mulia, 2007, hlm. 8

Robert A Baron, Social Psychology; Psikologi Sosial, terj. Ratna Djuwita, Jakarta: Penerbit Erlangga, 2003, ed. X jil. I, hlm. 130.

Rohmalina Wahab, Pisikologi Belajar, Jakarta: Rajawali Pres, 2016, hal. 159.

Romlah, Psikologi Pendidikan, Malang: Universitas Muhammadiyah Malang, 2010, hlm. 65

S. Harahap, Penegakan Moral Akademik Didalam dan Luar Kampus, Jakarta: Raja Grafindo, 2006. hal.75.

Sebagaimana dikutip oleh M. Nur Ghufron, Teori-Teori Psikologi, Yogyakarta: Ar Ruzz Media, 2011, hlm. 19

Sjarkawi, Pembentukan Kepribadian Anak; Peran Moral Intelektual, Emosional dan

Sosial sebagai Wujud Integritas Membangun Jati Diri, Jakarta: PT. Bumi Aksara, 2009, hlm. 26.

Suhardi Darmo, Analisi Data Variabel, Jakarta : Lembaga Penelitian UM. 2016, hal. 35 .

Supan Kusumamihardja, Studi Islamica, Jakarta: Girimukti Pasaka, 1985. hlm.9.

Syaparuddin \& Nasution, Manajemen Pembelajaran : QuantumTeaching, Jakarta: Raja Grafindo, 2000, hal. 105.

Veithzal Rivai, Kepemimpinan dan Perilaku Organisasi, Jakarta:Rajawali Press, 2009, hlm. 230 
Yatim Riyanto, Paradigma Baru Pembelajaran: sebagai Referensi bagi Guru/Pendidik dalam Implementasi Pembelajaran yang Efektif dan Berkualitas, Jakarta: Kencana, 2010, hlm 252. 